\title{
Challenges and Opportunities of Agribusiness in Post-Covid-19 Situation in India: A Review
}

\author{
Arka Das* \\ School of Agri-business \& Rural Management, Dr. Rajendra Prasad Central Agricultural \\ University, India \\ *Corresponding author
}

\section{A B S T R A C T}

\section{Keywords}

Agribusiness, Agriculture, Covid19 , Coronavirus, Opportunity

\section{Article Info}

Accepted: 24 July 2020 Available Online: 10 August 2020
The whole world is in a critical condition for the coronavirus. India is also badly affected by this dangerous virus. Every day the country is losing someone. The Indian economy has also suffered for coronavirus. India has taken many steps to control this situation but it was difficult to control. The effect of coronavirus is increasing rapidly. In this situation Coronavirus damaged the agriculture sector. Farmers were badly affected by coronavirus. The total supply chain disrupted for the lockdown. In this dark moment, the agribusiness has shown a little light. Coronavirus has created many opportunities in this sector that can help the peoples of India in the future. Also, it can help to improve the Indian economy.

\section{Introduction}

At a time when the whole world was struggling to cope with the effects of the coronavirus, India had taken a very important decision to save the people of the country from the coronavirus. The Indian government declared 21 days national lockdown from $25^{\text {th }}$ March2020 to $14^{\text {th }}$ March 2020. While it is not easy to lockdown a country of 1.3 billion people, the Indian government tried hard to do lockdown (1). This time the government tried to reduce the incidence of coronavirus but failed. Towards the end of the first phase of lockdown, when the outbreak of corona began to increase, the government again announced a 19 days lockdown with some relaxation. In the second phase of lockdown, the government divided the area into three zones: red, orange and Green. The worst affected areas were in the Red zone and the full safe area was the Green zone where no coronavirus effect was observed (2). Since then, the government has increased the lockdown in two more phases as the impact of coronavirus continues to grow day by day and has done so until $31^{\text {st }}$ May 2020(3).

In the middle of this lockdown, the government of India first announced a relief 
package of Rs 1.7 lakh crore to help the poor people of the country(4). Even after the situation worsened, the Honorable Prime Minister of India announced an economic package of 20 lakh crore which is 10 percent of GDP (5).

Most of the country's industry and service sectors were shut down during the lockdown but the agriculture sector was exceptional. Peoples can't live without food so the government has made every effort to keep running the agriculture and food sector. The agriculture sector is one of the essential sectors. Usually, the Rabi crop is harvested in April or May and the Kharif crop is planted a few days later but it has become a challenge for lockdown. Although the production of Rabi crop in the country was good in 2020, but the farmers faced many difficulties during cultivation.(6). In order for coronavirus to come, the agribusiness sector has had to face many difficulties but also many opportunities have been created in this sector. Agribusiness can play an important role in fixing the fragile state of the Indian economy caused by the coronavirus (7).

\section{Importance of agribusiness in Indian economy}

The contribution of agribusiness to the Indian economy is crucial. A large share of national income comes from the agriculture sector.13.9 percent of GDP came from the agriculture sector during 2013-14. Agribusiness can easily solve India's employment problem. A large part of the people of India involved in agriculture. Near about $52 \%$ of people in India are involved in agriculture (8).People can also increase their purchasing ability with their own income by associating with agribusiness. Farmer's in come is a big problem in India that can be solved through agribusiness development. Through advanced agribusiness methods, farmers can easily sell their crops at a good price and increase their profit. Farmers can also increase their production if the demand for goods increases with the help of advanced marketing (9). If production increases, India will be able to export more which will help the Indian economy to move forward. Between 2001 and 2010, agriculture exports grew by $16.3 \%$ in India (8). A systemic agribusiness plan can improve product quality, packaging etc. which helps to rise exports. Agriculture meets the demand for raw material that is needed in various industries (9).

\section{Impact of covid-19 in Indian agribusiness}

The coronavirus has had an unimaginable impact on various sectors of India. The agriculture sector has not escaped its onslaught. Farmers and agriculture-related industries both have gone through a difficult time for the coronavirus. The effects of the coronavirus on agriculture were -

Unfavorable condition to harvest the rabi crop and to plant kharif crop: Due to lockdown since March, the farmers had to face many difficulties for harvesting rabi crop. In India, rabi crop is harvested in April or May but due to lockdown, the harvest process was uncertain for the labour crisis. Workers returned home for fear of the coronavirus and for the lockdown. Also, farmers faced difficulties in planting Kharif crops due to a lack of labour. Farmers could easily solve their problems by using advanced farming machines in agriculture but most of the Indian farmers were poor and could not rent or buy an advanced farming machine. Besides, it is difficult to find skilled drivers to run the farming machines. Another big problem was that most of the fertilizer, pesticide, and herbicide stores were closed for the lockdown (10). 
Price variation: As a rest of the lockdown, the prices of perishable agricultural commodities went down due to the closure of hotels, restaurants, etc. The prices of vegetables and fruits were varying place wise. Many food prices have risen as a result of transportation problems and increased transportation costs (11). Poultry producers were in a lot of trouble for being misrepresented like poultry bird carries coronavirus. So, the poultry price went down sharply.

Disrupted supply chain: The workers all returned home for fear of coronavirus and lockdown (12). Loading and unloading were difficult due to the shortage of labour during the lockdown. Transportation was also a major inconvenience. Even though the train service is running, it was not possible to reach all parts of India by train. The trucks were running less in lockdown period. For this, there was a problem with supply chain.

Storage problem: The Fertilizer industry produced fertilizer during lockdown but it was difficult to reach the market. Fertilizer is needed everywhere in India. Due to transportation difficulties and labour shortages or loading and unloading during lockdown, they could not deliver fertilizer to all parts of the country. The industries did not have adequate storage for which they were in trouble (13).

\section{Role of government of India}

The Government of India has played a very important role in this dire situation. Those are-

The Government amended the Essential Commodities Act to enable better price realization for farmers which can end in the deregulation of costs for food stuffs (14).

The Indian government first announced a package of Rs 1.7 lakh crore. With the help of this money, governmentprovided free rice or wheat $(5 \mathrm{~kg}$ per month) and pulse (1 kg per month) to 80 crore poor peoples of India and gave Rs 2000 to almost 9 crore farmers in the month of April 2020 (15).

When the condition was getting worse, The Indian government announced an incredible package of 20 lakh crore to save Indians in a pandemic situation. National Bank considered an additional working capital of Rs 30,000 crore for agriculture and rural development. Along with it, there is also a Rs 40000 crore increase in allocation for MGNREGA with the aim of increment in employment opportunities (16).

Under the Kisan Credit Card scheme also gave Rs 2 lakh crore to boost the credit of 2.5 crore farmers, Rs 1 lakh crore for Agri infrastructure development.

The Government of India has declared a scheme of Rs 10000 crore for fisherman and Rs 15000 crore for animal husbandry infrastructure.

During the lockdown period, more than INR 74,300 crores MSP purchases were made. (17).

The Indian government has launched a new app called 'Kisan Rath' so that there is no hassle in transporting agricultural products during the lockdown. This app helps to communicate with transporters and more than 2000 transporters are connected with this app (18).

For the benefit of the farmers, the Government of India has increased the minimum support price of 14 kharif crops for 2020-21. So, Farmers can earn more.

\section{Post-covid-19 challenges}

As the days go by, coronavirus is taking on more and more outbreaks. Coping with the 
effects of coronavirus, it is the biggest challenge to run the agribusiness sector properly. The number of labours in the agribusiness sector is much lower due to fear of coronavirus and inconvenience of transportation. In this situation, it is a challenge to market the rabi crop properly. Keeping the Agri supply chain running is one of the big challenges. Due to the lacking of demand for Agro-processing and value addition industries, the economic slowdown is also faced by Dairy, livestock, fisheries, and poultry sector businesses. Farmers are being forced to sell their crops at a low price. As a result, farmers become more financially weak. The number of storages of agricultural products needs to be increased (Table 1).

Table.1 MSP for kharif crop for 2020-21(19)

\begin{tabular}{|c|c|c|c|c|}
\hline $\mathbf{S L}$ & $\mathbf{C R O P}$ & $\begin{array}{c}\text { MSP OF } \\
\text { KHARIF CROP } \\
\mathbf{( 2 0 2 0 - 2 1 )}\end{array}$ & $\begin{array}{c}\text { INCREASED } \\
\text { MSP }\end{array}$ & $\begin{array}{c}\text { RETURN } \\
\text { OVERCOST }\end{array}$ \\
\hline $\mathbf{1}$ & PADDY (COMMON) & 1868 & 53 & 50 \\
\hline $\mathbf{2}$ & PADDY (GRADE A) & 1888 & 53 & - \\
\hline $\mathbf{3}$ & JOWAR (HYBRID) & 2620 & 70 & 50 \\
\hline $\mathbf{4}$ & JOWAR (MALDANDI) & 2640 & 70 & - \\
\hline $\mathbf{5}$ & BAJRA & 2150 & 150 & - \\
\hline $\mathbf{6}$ & RAGI & 3295 & 145 & 50 \\
\hline $\mathbf{7}$ & MAIZE & 1850 & 90 & 58 \\
\hline $\mathbf{8}$ & TUR (ARHAR) & 6000 & 200 & 50 \\
\hline $\mathbf{9}$ & MOONG & 7196 & 146 & 50 \\
\hline $\mathbf{1 0}$ & URED & 6000 & 300 & 50 \\
\hline $\mathbf{1 1}$ & GROUNDNUT & 5275 & 185 & 50 \\
\hline $\mathbf{1 2}$ & SUNFLOWER SEED & 5885 & 235 & 50 \\
\hline $\mathbf{1 3}$ & SOYBEAN (YELLOW) & 3880 & 170 & 50 \\
\hline $\mathbf{1 4}$ & SESAMUM & 6855 & 370 & 50 \\
\hline $\mathbf{1 5}$ & NIGERSEED & 6695 & 755 & - \\
\hline $\mathbf{1 6}$ & COTTON & 5515 & 260 & \\
\hline $\mathbf{1 7}$ & COTTON & 5515 & 275 & \\
\hline
\end{tabular}

Source: www.pib.gov.in

\section{Post-covid-19 opportunities}

As coronavirus slowdown the agribusiness sector, it creates lots of new opportunities for agribusiness. That's are-

Farm Machinery: Due to COVID-19 and lockdown, there was a lack of labour to perform the agricultural activity. Farmers were in a lot of trouble when it came to harvesting rabi crops and planting kharif crops (20). However, this has opened the door for the mechanization approach within the agricultural sector with transformational change where pieces of machinery are often utilized in the feasible areas having larger hectares of land to conduct agricultural activities (21).

E-commerce: Due to the coronavirus and lockdown, the demand for online shopping has increased a lot. People showed their 
interest in online shopping instead of traditional shopping. In the month of April 2020, the demand for E-commerce increased by $206 \%$ in the world. So, e-commerce is a new opportunity for agribusiness (22).

\section{Entrepreneurship opportunity}

We all need food to survive. Different foods have different advantages. Milk, meat, fish, eggs, etc. play a very important role in combating malnutrition. In addition, these products have emerged as a possible way to deal with food security problems. This sector has become more important after the outbreak of coronavirus. So, there is a lot of entrepreneurship opportunity after the outbreak of coronavirus.

\section{Farmer Producer Organization (FPO)}

Farmer Producer organizations (FPO) and Farmer Producer Companies (FPC) play an important role in improving the agribusiness sector. It helps farmers in cultivation and help to reach the cultivated crop to market. The usefulness of FPO and FPC has come to the fore during the lockdown. The Government of India has announced 10000 FPO for 2020-21. So, it has a great opportunity after coronavirus (23).

In conclusion the Coronavirus changed the traditional life of the people. People now thoughts their daily life in a different way. Lots of people now interested in modern technology. Coronavirus taught us how to develop our daily life with technology. Before coronavirus, Maximum peoples of India were not interested in online shopping but then corona forces us to thought about this modern system. Coronavirus brings many problems in agriculture sector but as well as it also brings lots of opportunities for agribusiness. Now people don't think about going to the market for shopping, they want to buy vegetables, fruits or daily need sitting at the home. In the agriculture sector, Farmer's income is a big problem. Coronavirus opens the door of farm machinery that can increase productivity as well as farmer's income. The farmer can increase their profit with proper marketing, FPO and FPC can show a better way of marketing to the farmers. In India One of the most problems is employment. This employment problem can be reduced with the help of agribusiness. Young people have no interest in the traditional farming system but they have lots of interest in the modern farming system. Lots of entrepreneurship opportunities are created in the agriculture sector post-covid-19.

\section{References}

Ray, D., Subramanian, S., and Vandewalle, L. (2020). India's lockdown (No. BOOK). Centre for Economic Policy Research.

Arumugam, D. U., and Kanagavalli, D. G. (2020). COVID-19: Impact of Agriculture in India. Aegaeum Journal, 8(5).

Pachori, R. (2020). Lockdown-4: Impact of lockdown on COVID-19 scenario in India. International Journal of Preventive Medicine, 11(1), 96.

Balajee, A., Tomar, S., and Udupa, G. (2020). Fiscal Situation of India in the Time of COVID-19. Available at SSRN 3571103.

Aayog, N. Towards A Clean energy economy. Swami, M. (2020). Consumption growth constrained by demand compression. Centre for Monitoring Indian Economy (CMIE).

Altieri, M. A., and Nicholls, C. I. (2020). Agroecology and the reconstruction of a post-COVID-19 agriculture. The Journal of Peasant Studies, 1-18.

Mohit, M., Mahajan, A., and Mahajan, R. Indian Agriculture Exports in the era of WTO: performance and policy Issues. 
Usapkar, R. V., and Parab, S. D. Role of Agriculture Marketing in Economic Development in India.

Khandagale, R., Hattali, M., and Godase, D. (2020). Impact of Covid-19 on Indian Agriculture and its Scenario. Journal of Global Biosciences, 9(6), 7510-7521.

Narayanan, S, (2020). How India's agrifood supply chains fared during the Covid19 lockdown, from farm to fork, IFPRI Blog.https://www.ifpri.org/blog/howindias-agrifood-supply-chains-faredduring-covid-19-lockdown-farm-fork

Mahenra, S, D. (2020). Addressing COVID19 impacts on agriculture, food security, and livelihoods in India, IFPRI

Blog.https://www.ifpri.org/blog/addres sing-covid-19-impacts-agriculturefood-security-and-livelihoods-india

Chander, S. (2020). Fertilizer Industry Amidst COVID-19 Crisis. Indian Journal of Fertilisers 16 (5): 414-415.

Rawal, V., Kumar, M., Verma, A., and Pais, J. (2020). COVID-19 Lockdown: Impact on Agriculture and Rural Economy. Society for Social and Economic Research.

Verma, S., Saharan, A., Polcumpally, A. T., and Biswas, M. Tentacles of COVID19 in India: Impact on Indian Economy, Society, Polity and Geopolitics.

Aayog, N. Towards A Clean Energy Economy.

Kedia, S., Sinha, R., Pandey, R.,
Bhattacharjya, S., Syiemlieh, J. D., Chaudhury, S. and Ghosh, P. (2020). Greening Post Covid-19 Economic Recovery in India.

Mahapatra, S. K. (2020). Smartphone Apps for Agri-information dissemination during Covid19 lockdown. Biotica Research Today, 2(5), 116-119.

PIB Delhi. (2020). Minimum Support Prices (MSP) for Kharif Crops for marketing season 2020-21. Retrieved from https://pib.gov.in/PressReleasePage.asp $\mathrm{x}$ ?PRID $=1628348$

Kharbikar, H. L., Radhika, C., Naitam, R. K., Daripa, A., Malav, L., and Raghuvanshi, M. S. Consequences of COVID-19 Pandemic and Lockdown on Food and Agribusiness Sector in India.

Solomon, S., Rao, G. P., and Swapna, M. (2020). Impact of COVID-19 on Indian Sugar Industry. Sugar Tech, 1.

Barnes, S. J. (2020). Information management research and practice in the postCOVID-19 world. International Journal of Information Management, 102175.

Muringatheri, M. (2020, May 10). Agribusiness to offer new opportunities post-COVID. Retrieved 31July 2020. From The Hindu. https://www.thehindu.com/news/nation al/kerala/agribusiness-to-offer-newopportunities-postcovid/article31552634.ece

\section{How to cite this article:}

Arka Das. 2020. Challenges and Opportunities of Agribusiness in Post-Covid-19 Situation in India: A Review. Int.J.Curr.Microbiol.App.Sci. 9(08): 2924-2929.

doi: https://doi.org/10.20546/ijcmas.2020.908.327 